\title{
Toxicity of Sodium Bicarbonate to Fish from Coal-Bed Natural Gas Production in the Tongue and Powder River Drainages, Montana and Wyoming
}

This study evaluates the sensitivity of aquatic life to sodium bicarbonate $\left(\mathrm{NaHCO}_{3}\right)$, a major constituent of coalbed natural gas-produced water. Excessive amounts of sodium bicarbonate in freshwater streams and rivers may adversely affect the ability of fish to regulate their ion uptake. The study area includes the Tongue and Powder River drainages within the Powder River Basin in southeastern Montana and northeastern Wyoming.

In the past decade, thousands of coal-bed natural gas wells have been drilled within the Powder River Basin, one of the largest sources of coal in the United States. The process of gas extraction involves drilling water wells into underground coal seams (fig. 1). Water

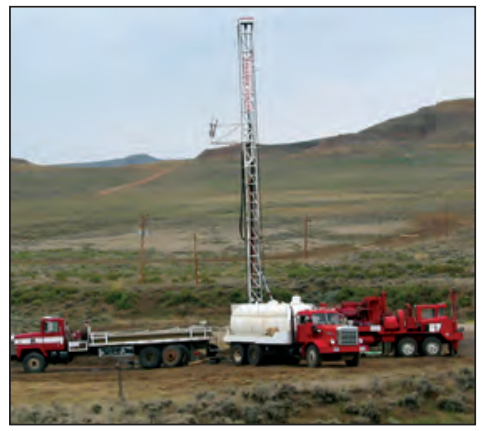

Figure 1. Coal-bed natural gas drilling in Montana.

from the aquifer is then drawn through the well, which decreases water pressure and releases the methane gas. The gas rises up the wellbore where it is collected and distributed via pipeline for various energy uses. The water becomes a waste product and, depending on local circumstances, is released to streams. Sodium bicarbonate is one of the constituents in the wastewater; it can reach levels over $1,000 \mathrm{mg} / \mathrm{L}$ (milligrams per liter).
Neither the U.S. Environmental Protection Agency nor the State of Montana has established a sodium bicarbonate water quality criterion or standard for aquatic life.

Sodium bicarbonate is not naturally present in appreciable concentrations within the surface waters of the Tongue and Powder River drainages and the large concentrations have been shown to be acutely toxic to native fish (Mount and others, 1997). In 2003, with funding and guidance provided by the U.S. Environmental Protection Agency, the Montana Fish, Wildlife, and Parks and the U.S. Geological Survey initiated a collaborative study on the potential effects of coalbed natural gas wastewater on aquatic life. A major goal of the study is to pro- vide information to the State of Montana Water Quality Program needed to develop an aquatic life standard for sodium bicarbonate. The standard would allow the State, if necessary, to establish targets for sodium bicarbonate load reductions.

The collaborative study focuses on the acute and chronic toxicity of sodium bicarbonate on select fish species. Understanding the concentration at which sodium bicarbonate is toxic to fish provides the thresholds needed to establish water quality standards. In 2004, field assessments were added (fig. 2) to define the presence or absence of fish species in the target area, define additional species of interest for laboratory studies, and validate results found in the laboratory.

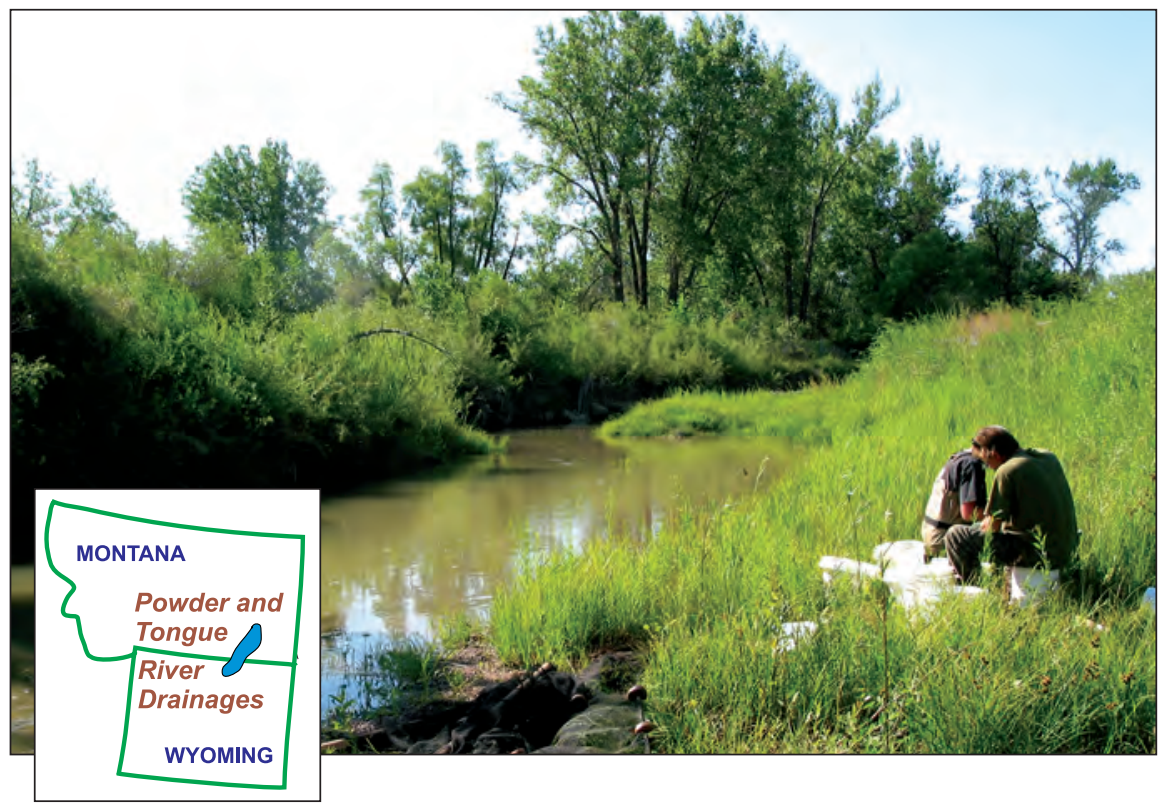

Figure 2. Researchers conduct field assessments to define the presence or absence of fish in the Tongue and Powder River drainages, which flow from Wyoming to Montana where they join the Yellowstone River. Extraction of coal-bed natural gas in the area can release large amounts of sodium bicarbonate into the streams. 


\section{Acute Toxicity}

Acute toxicity experiments were designed to determine the median lethal concentration of sodium bicarbonate to fish (table 1). The experiments were conducted over a period of 96 hours. Fish were exposed to various amounts of sodium bicarbonate in simulated river water (fig. 3). Commercially-available salts were added to distilled or well water, which was formulated to represent the major ion composition of either the Tongue or Powder Rivers. The experiments were performed on early life stages (newly hatched and older fry) of fish native to the Tongue and Powder River drainages-fathead minnow, white sucker, and pallid sturgeon (fig. 4).

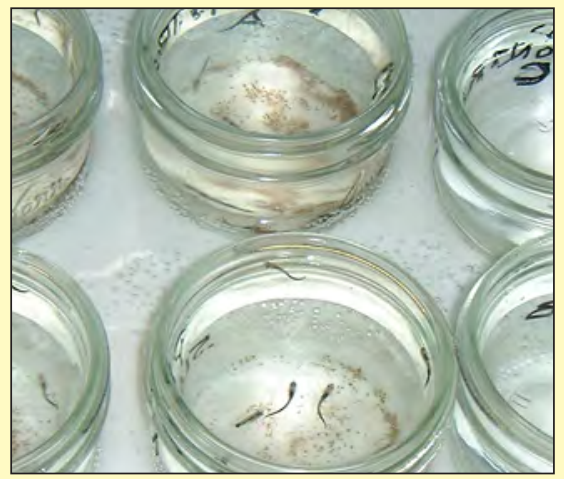

Figure 3. To study acute toxicity, fish fry are exposed to different concentrations of sodium bicarbonate in simulated river water over a 96 -hour period.
Figure 4. Fish

native to the Tongue and Powder River drainages were used for experiments. $A$, The fathead minnow (Pimephales promelas). $B$, The white sucker (Catostomus commersonii), which is not normally used as a laboratory animal, but is very prominent in the study area. C, The pallid sturgeon (Scaphirhynchus albus), an endangered species that inhabits the Yellowstone River.
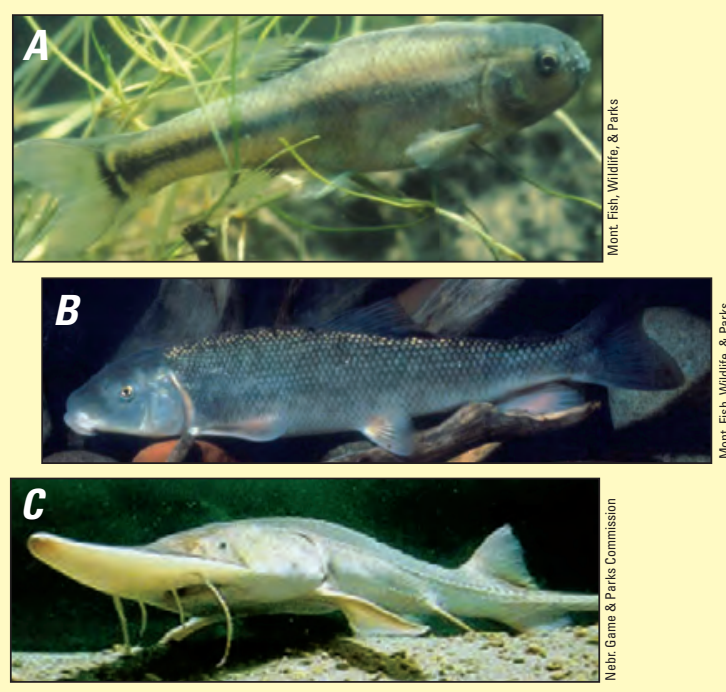

Table 1. Acute toxicity results indicate that the concentrations of sodium bicarbonate that cause 50 percent of the exposed fish to die (LC50) are the smallest in 4-day old fathead minnows in simulated Powder River water and pallid sturgeon in simulated Tongue River water. Fathead minnows, pallid sturgeon, and white sucker were all able to withstand greater amounts of sodium bicarbonate if exposed after they were 21-days old.

\begin{tabular}{|c|c|c|c|}
\hline Species & $\begin{array}{c}\text { Age of } \\
\text { fish in days } \\
\text { (post-hatch) }\end{array}$ & $\begin{array}{l}\text { Water being } \\
\text { simulated }\end{array}$ & $\begin{array}{c}\text { Sodium bicarbonate } \\
\text { LC50 ( } \pm 95 \% \mathrm{Cl}) \\
\text { (mg/L) }\end{array}$ \\
\hline Fathead minnow & 4 days & Powder River & $1,643(1,188-2,377)$ \\
\hline Fathead minnow & 4 days & Tongue River & $>4,000 *$ \\
\hline Fathead minnow & 39 days & Tongue River & $5,526(5,057-6,038)$ \\
\hline White sucker & 22 days & Tongue River & $5,121(4,049-6,678)$ \\
\hline White sucker & 22 days & Powder River & $5,421 *$ \\
\hline Pallid sturgeon & 4 days & Powder River & $1,158(1,103-1,216)$ \\
\hline Pallid sturgeon & 4 days & Tongue River & 1,828 \\
\hline
\end{tabular}

Test did not meet EPA guidance for minimum number of organisms per test concentration.

\section{Chronic Toxicity}

Flow-through experiments were conducted in the laboratory to determine long-term or delayed toxic effects of sodium bicarbonate on fish. These experiments had continuous supplies of water that allow fish to survive and grow over long periods of time. Water quality parameters were controlled so the effects due only to sodium bicarbonate could be isolated (fig. 5).

To date, three chronic studies have been performed, two on the fathead minnow and one on the white sucker (fig. 4). Laboratory water was simulated to mimic the Tongue River (the control). Sodium bicarbonate was added in varied $\mathrm{mg} / \mathrm{L}$ concentrations to the control water. The fish were exposed from fertilization until 43 or 60 days post-hatch.
Fertilized eggs were used to initiate the studies and continued though post swim-up. Because the small size of fathead minnow and white sucker eggs makes the exact number of eggs difficult to assess, the calculated percent hatch for control and experimental concentrations was estimated and statistical analyses were not performed on the data. White sucker are not a typical species used in laboratory experiments; the eggs were collected from wild fish and the percent hatch was consequently small (table 2).

Because most of the treatments caused significant mortality during Experiment 1 for fathead minnows, a second experiment was conducted to include additional treatments and better define the

(Continued on page 3)
Table 2. Estimated percent hatch for the native fathead minnows and white suckers exposed to sodium bicarbonate in simulated Tongue River water for chronic toxicity tests.

\begin{tabular}{ccc}
\hline $\begin{array}{c}\text { Sodium } \\
\text { bicarbonate } \\
\text { treatment } \\
\text { (mg/L) }\end{array}$ & $\begin{array}{c}\text { Estimated hatch } \\
\text { (percent) }\end{array}$ \\
\hline & $\begin{array}{c}\text { Fathead } \\
\text { minnow }\end{array}$ & $\begin{array}{c}\text { White } \\
\text { sucker }\end{array}$ \\
\hline Control & 63 & 23 \\
$500^{*}$ & 78 & 21 \\
800 & 69 & 29 \\
1,100 & 70 & NA \\
1,400 & 44 & 30 \\
\hline
\end{tabular}

Concentration was $450 \mathrm{mg}$ sodium bicarbonate per liter during white sucker experiment. 


\section{Chronic Toxicity (continued)}

point where significant mortality of fathead minnows might occur (table 3 ). White suckers appeared to tolerate greater concentrations of sodium bicarbonate than fathead minnows. No additional chronic experiment was conducted with white suckers.

Results of the chronic experiments indicated that survival in fathead minnows was significantly less than the controls in all sodium bicarbonate concentrations above $400 \mathrm{mg} / \mathrm{L}$ (table 3); however, in the treatments without significant mortality, growth was not affected. Early survival for white suckers appeared to be unaffected.

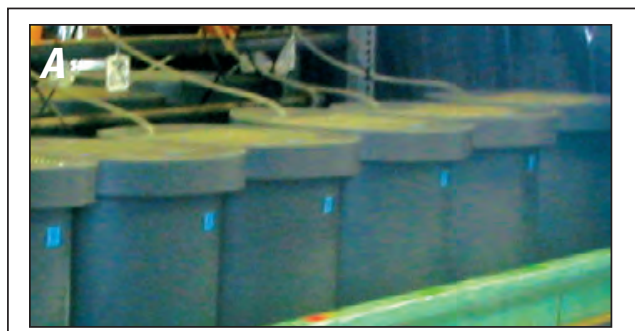

Figure 5. Chronic toxicity experiments were conducted in the laboratory "diluter," which mimics conditions in the Tongue River and allows for the study of various concentrations of sodium bicarbonate on fish. $A$, The grey tanks held the fish; simulated Tongue River water was added to some of the tanks as the "control" for comparisons. $B$, The remainder of the tanks received "exposure" waters, which consisted of various concentrations of sodium bicarbonate that were electronically metered into glass mixing chambers at the front of the diluter and added to the simulated Tongue River water.
As concentration and exposure time increased, so did the occurrence and severity of microscopic lesions in fathead minnows. After 60 days, fathead minnows from the $500 \mathrm{mg} / \mathrm{L}$ treatment had slightly increased incidence of kidney damage compared to the controls as defined by the greater number of regenerating tubules and focal degeneration that were observed in the kidneys of fish exposed to $500 \mathrm{mg} / \mathrm{L}$. The histology examinations and compilation of growth data for white sucker are not yet complete. In addition to measurements of survival, growth, and histology, $\mathrm{Na} / \mathrm{K}$ ATPase activity, and whole body ion contents are being determined to provide insight into how sodium bicarbonate might cause deaths of fish.



\section{Field Studies}

Field sampling began in July 2004 to determine fish species distribution at 15 selected sites in the Tongue and Powder River drainages and to evaluate the influence of water quality and habitat on fish species assemblages (table 4). Fish were collected by seining or electrofishing a 300 -meter section of

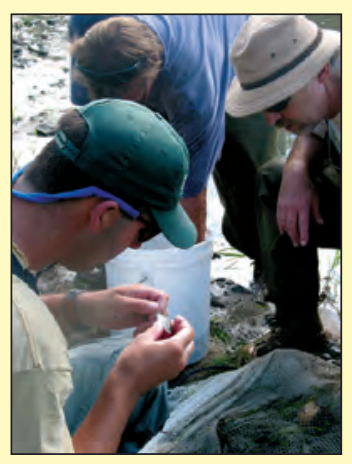
stream at each site. Fish and habitat measurements were collected to allow (1) the creation of a list of expected fish species at each site as predicted by the Warmwater Stream Assessment method (Quist and others, 2004), and (2) the calculation of an Index of Biological Integrity (Bramblett and others, 2003) for each site. Because the white sucker was one of the most prominent species present during the field sampling, it was subsequently used in the chronic toxicity study.

In 2005, funds were provided to the Montana Fish, Wildlife, and Parks and the USGS in Cheyenne, Wyoming to collect water quality data in conjunction with fish and habitat surveys being conducted in the Tongue, Powder, and Rosebud Creek drainages. These data will be combined with the 2004 survey data in order to create a database of fish species tolerances relative to levels of sodium bicarbonate and specific conductivity.

Table 3. Percent survival of fish exposed to sodium bicarbonate in laboratory water simulating the Tongue River.

$[\mathrm{m} / \mathrm{L}$, milligrams per liter; h, hour; d, day]

\begin{tabular}{|c|c|c|c|c|c|c|c|c|c|c|c|}
\hline \multicolumn{4}{|c|}{$\begin{array}{l}\text { Experiment 1, fathead minnow survival } \\
\text { (percent) }\end{array}$} & \multicolumn{4}{|c|}{$\begin{array}{l}\text { Experiment 2, fathead minnow survival } \\
\text { (percent) }\end{array}$} & \multicolumn{4}{|c|}{$\begin{array}{l}\text { Experiment 3, white sucker survival } \\
\text { (percent) }\end{array}$} \\
\hline $\begin{array}{l}\text { Treatment } \\
\qquad(\mathrm{m} / \mathrm{L})\end{array}$ & 96-h & $0-30-d$ & $30-60-d$ & $\begin{array}{l}\text { Treatment } \\
(\mathrm{m} / \mathrm{L})\end{array}$ & 96-h & $0-30-d$ & $30-60-d$ & $\begin{array}{l}\text { Treatment } \\
\quad(\mathrm{m} / \mathrm{L})\end{array}$ & 96-h & $0-25-d$ & $25-43-d$ \\
\hline Control & 94 & 89 & 96 & Control & 90 & 67 & 99 & Control & 64 & 54 & 69 \\
\hline 500 & 83 & 64 & 93 & 300 & 93 & 35 & 100 & 450 & 84 & 80 & 72 \\
\hline 800 & 55 & 33 & + & 400 & 90 & 57 & 100 & 800 & 90 & 53 & 82 \\
\hline 1,100 & 40 & 21 & + & 625 & 60 & 30 & 100 & ---- & ---- & ---- & ---- \\
\hline 1,400 & 8 & 2 & + & ---- & ---- & ---- & ---- & 1,400 & 94 & 52 & 45 \\
\hline
\end{tabular}

+ Sacrificed concentrations at day 37 
Table 4. General water chemistry, number of species, and number of fish observed during field assessments of 15 sites in the Tongue and Powder River drainages.

$\left[\mathrm{R}\right.$, river; $\mathrm{m}$, meter; ${ }^{\circ} \mathrm{C}$, degrees Celsius; $\mathrm{mg} / \mathrm{L}$, milligrams per liter, $\mu \mathrm{s} / \mathrm{cm}$, microSiemens per centimeter; s.u., standard units; $\mathrm{CaCO}_{3}$, calcium carbonate $]$

\begin{tabular}{|c|c|c|c|c|c|c|c|c|c|c|}
\hline Site & Date & $\begin{array}{c}\text { Mean } \\
\text { width } \\
(\mathrm{m})\end{array}$ & $\begin{array}{c}\text { Thalwag } \\
\text { depth } \\
\text { (m) }\end{array}$ & $\begin{array}{c}\text { Temp- } \\
\text { erature } \\
\left({ }^{\circ} \mathrm{C}\right)\end{array}$ & $\begin{array}{c}\text { Oxygen } \\
\text { (mg/L) }\end{array}$ & 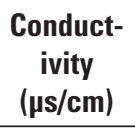 & $\begin{array}{c}\text { pH } \\
\text { (s.u.) }\end{array}$ & $\begin{array}{c}\text { Akalinity } \\
\text { (mg/L as } \\
\mathrm{CaCO}_{3} \text { ) }\end{array}$ & $\begin{array}{c}\text { Number of } \\
\text { fish } \\
\text { (species) }\end{array}$ & $\begin{array}{c}\text { Number of } \\
\text { fish } \\
\text { (individuals) }\end{array}$ \\
\hline Powder R at Locate & $7 / 25 / 2004$ & 8.34 & 0.077 & 30.1 & 7.00 & 2,950 & 8.37 & 309 & 5 & 468 \\
\hline Little Powder R nr Broadus & $7 / 24 / 2004$ & 7.89 & 0.66 & 20.6 & 8.51 & 1,730 & 8.76 & 430 & 10 & 783 \\
\hline Powder R nr Moorhead & $7 / 24 / 2004$ & 32.60 & 0.26 & 15.7 & 8.21 & 2,295 & 8.35 & 163 & 5 & 246 \\
\hline Powder R at Sussex & $7 / 21 / 2004$ & 13.40 & 0.21 & 29.6 & 9.35 & 5,550 & 8.44 & 296 & 5 & 475 \\
\hline Clear Creek & $7 / 22 / 2004$ & 14.00 & 0.27 & 23.8 & 6.27 & 1,988 & 8.14 & 270 & 13 & 221 \\
\hline Crazy Woman Creek & $7 / 22 / 2004$ & 4.85 & 0.26 & 25.0 & 10.00 & 2,981 & 8.35 & 320 & 7 & 1,216 \\
\hline Tongue $\mathrm{R}$ at Miles City & $7 / 25 / 2004$ & 19.10 & 0.26 & 26.3 & 10.70 & 1,210 & 8.48 & 262 & 12 & 262 \\
\hline Tongue $\mathrm{R}$ at Brandenburg & $7 / 25 / 2004$ & 25.90 & 0.83 & 20.4 & 7.44 & 766 & 8.50 & 200 & 12 & 171 \\
\hline Tongue R nr Birney & $7 / 23 / 2004$ & 19.10 & 0.34 & 20.9 & 7.92 & 575 & 8.49 & 206 & 8 & 206 \\
\hline Hanging Woman Creek & $7 / 23 / 2004$ & 2.98 & 0.09 & 17.9 & 6.50 & 2,879 & 8.68 & 660 & 5 & 256 \\
\hline Tongue $\mathrm{R}$ blw dam & $7 / 19 / 2004$ & ---- & ---- & ---- & ---- & ---- & ---- & ---- & 8 & 22 \\
\hline Tongue $\mathrm{R}$ at Stateline & $7 / 19 / 2004$ & 35.30 & 0.72 & 23.8 & 6.04 & 647 & 8.46 & 204 & 12 & 74 \\
\hline Prairie Dog Creek & $7 / 21 / 2004$ & 5.10 & 0.42 & 18.5 & 7.94 & 1,518 & 8.38 & 326 & 4 & 28 \\
\hline Goose Creek & $7 / 20 / 2004$ & 15.40 & 0.43 & 23.8 & 11.5, & 724 & 8.80 & 252 & 8 & 80 \\
\hline Tongue $\mathrm{R}$ at Monarch & $7 / 20 / 2004$ & 21.00 & 0.44 & 26.2 & 9.95 & 355 & 8.77 & 168 & 7 & 90 \\
\hline
\end{tabular}

\section{Findings to Date}

It appears that within 96 hours, concentrations of sodium bicarbonate of 1,100 to $1,600 \mathrm{mg} / \mathrm{L}$ will cause 50 percent mortalities in early lifestage fish under the Tongue or Powder River conditions. The concentration is reduced to $780 \mathrm{mg} / \mathrm{L}$ if fathead minnows are exposed to sodium bicarbonate shortly after fertilization rather than at 4-days old. Furthermore, significant mortalities of greater than 30 percent will occur if fish in the Tongue River are exposed to $400 \mathrm{mg} / \mathrm{L}$ of sodium bicarbonate for 30 days. Fathead minnows appear to be the most sensitive species followed by pallid sturgeon and then white suckers.

\section{Future Directions}

We will continue to prepare a database that defines the toxicity of sodium bicarbonate to fish and other aquatic organisms in the Tongue and Powder Rivers. These data can then be used by Federal and State agencies to define water quality criterion for sodium bicarbonate. The field data that describes fish presence or absence will be interpreted with the laboratory results and the ongoing monitoring data currently being gathered by USGS to describe fish tolerances in the Powder and Tongue Rivers. We plan to conduct on-site toxicity experiments to assess the survival of fish under natural conditions, though such experiments lack the control provided in the laboratory.

In addition to providing data about effects of sodium bicarbonate on survival and growth of fish, toxicity studies can provide information about the health of fish that may survive the exposure, or "sub-lethal" effects of sodium bicarbonate. We collected samples during the chronic experiments to define some sublethal effects of sodium bicarbonate and to help explain how sodium bicarbonate might work to deteriorate the health of fish. Future plans include measuring and interpreting analyses of histology, $\mathrm{Na} / \mathrm{K}$ ATPase activity, and whole body ion content in samples collected to date.

\section{Acknowledgements}

This work was funded by the U.S. Environmental Protection Agency with matching funds from Montana Fish, Wildlife, and Parks and the USGS. Brady Morris and Joseph Meyer, University of Wyoming, Brad Mueller, USGS, and Kurt Hill, Montana Fish, Wildlife, and Parks provided professional and technical assistance.

\section{For Information}

Don Skaar, Montana Fish, Wildlife and Parks; 406-444-5686; dskaar@mt.gov

Aïda Farag, U.S. Geological Survey; 307-733-2314, extension 11;

aida_farag@usgs.gov

David Harper, U.S. Geological Survey; 307-733-2314, extension 14;

david_harper@usgs.gov

\section{References Cited}

Bramblett, R.G., Johnson, T.R., Zale, A.V., and Heggem, D., 2003, Development of biotic integrity indices for prairie streams in Montana using fish, macroinvertebrate, and diatom assemblages: Bozeman, Mont, Montana Coop Fishery Research Unit.

Mount, D.R., Gulley, D.D., Hockett, J.R., Garrison, T.D., and Evans, J.M., 1997, Statistical models to predict the toxicity of major ions to Ceriodaphnia dubia, Daphnia magna, and Pimephales promelas (fathead minnows): Environmental Toxicology and Chemistry 16, p. 2009-2019.

Quist, M.C., Hubert, W.A., and Rahel, F.J., 2004, Warmwater stream assessment manual: Cheyenne, Wyo., Wyoming Game \& Fish Department, Fish Division. 